\title{
Stability of Levothyroxine in Sodium Chloride for IV Administration
}

\author{
Dawn K Strong, Diane Decarie, and Mary H H Ensom
}

\begin{abstract}
Background: Levothyroxine by IV administration is often prescribed in the intensive care unit for the management of potential solid organ donors, following declaration of brain death and provision of consent for organ donation. Published data on the stability of levothyroxine in IV solutions are limited.
\end{abstract}

Objective: To evaluate the physical compatibility and chemical stability, over a 24 -h period, of 2 concentrations of levothyroxine in $0.9 \%$ sodium chloride with storage at room temperature and with exposure to or protection from light.

Methods: Levothyroxine solutions $(0.4 \mu \mathrm{g} / \mathrm{mL}$ and $2.0 \mu \mathrm{g} / \mathrm{mL})$ were prepared in $50-\mathrm{mL}$ minibags of $0.9 \% \mathrm{NaCl}$ and stored at room temperature $\left(25^{\circ} \mathrm{C}\right)$ with exposure to or protection from light. Samples were collected from each minibag at time 0 and after 0.5, 1.0, 1.5, 2.0, $3.0,4.0,8.0,12.0$, and $24.0 \mathrm{~h}$. The samples were analyzed in triplicate with a validated stability-indicating high-performance liquid chromatography method using ultraviolet detection. A solution was considered stable if it maintained $90 \%$ of its initial concentration of levothyroxine. Changes in colour, clarity, and $\mathrm{pH}$ were assessed to determine the physical compatibility of the solutions.

Results: All samples remained clear, colourless, and free of precipitate throughout the study, and there were no significant changes in $\mathrm{pH}$. Based on the $95 \%$ confidence interval of the slope of the curve relating concentration to time determined by linear regression, solutions of levothyroxine with concentration $0.4 \mu \mathrm{g} / \mathrm{mL}$ would maintain at least $90 \%$ of the initial concentration for $16.9 \mathrm{~h}$ with exposure to light and for $18.0 \mathrm{~h}$ if kept in the dark. Solutions of levothyroxine with concentration $2.0 \mu \mathrm{g} / \mathrm{mL}$ would maintain at least $90 \%$ of the initial concentration for $6.5 \mathrm{~h}$ with exposure to light and for $12.0 \mathrm{~h}$ if kept in the dark, with $95 \%$ confidence.

Conclusions: Extemporaneously prepared solutions of levothyroxine in $0.9 \% \mathrm{NaCl}$ can be expected to remain stable for at least $6.5 \mathrm{~h}$ if stored without protection from light and at least $12 \mathrm{~h}$ if stored in the dark. Stability is related to concentration, with more dilute solutions having greater stability.

Key words: levothyroxine, IV administration, stability, organ donation

Can J Hosp Pharm 2010;63(6):437-443

\section{RÉSUMÉ}

Contexte : La lévothyroxine administrée par injection i.v. est souvent prescrite dans les unités de soins intensifs lors de la prise en charge des donneurs potentiels d'organe, après avoir déclaré la mort cérébrale et avoir obtenu le consentement pour le don d'organe. Les données publiées sur la stabilité de la lévothyroxine dans des solutions intraveineuses sont toutefois limitées.

Objectif : Évaluer la compatibilité physique et la stabilité chimique, sur une période de 24 heures, de solutions de lévothyroxine préparées en deux concentrations dans du chlorure de sodium à 0,9\%, entreposées à la température ambiante à l'abri ou non de la lumière.

Méthodes : Les solutions de lévothyroxine $(0,4 \mu \mathrm{g} / \mathrm{mL}$ et $2,0 \mu \mathrm{g} / \mathrm{mL})$ ont été préparées dans des minisacs de $50 \mathrm{~mL}$ de chlorure de sodium à $0,9 \%$ qui ont été entreposés à la température ambiante $\left(25^{\circ} \mathrm{C}\right)$ et exposés ou non à la lumière. Des échantillons ont été recueillis de chaque minisac à $0,0,5,1,1,5,2,3,4,8,12$ et 24 heures. Les échantillons ont été analysés en triple à l'aide d'une épreuve validée mesurant la stabilité par chromatographie liquide haute performance avec détection ultraviolette. Les solutions étaient considérées comme stables si elles conservaient $90 \%$ de la concentration initiale de lévothyroxine. La compatibilité physique a été évaluée en contrôlant tout changement dans la couleur, la limpidité et le $\mathrm{pH}$ des solutions de lévothyroxine.

Résultats : Tous les échantillons sont demeurés limpides, incolores et sans précipité tout au long de l'étude, et n'ont présenté aucun changement significatif du pH. D'après l'intervalle de confiance à $95 \%$ de la pente de la courbe de la concentration en fonction du temps déterminée par régression linéaire, les solutions de lévothyroxine à $0,4 \mu \mathrm{g} / \mathrm{mL}$ conservaient au moins $90 \%$ de la concentration initiale pendant 16,9 heures lorsqu'elles étaient exposées à la lumière et pendant 18,0 heures lorsqu'elles étaient à l'abri de la lumière. Les solutions de lévothyroxine à $2,0 \mu \mathrm{g} / \mathrm{mL}$ conservaient au moins $90 \%$ de la concentration initiale pendant 6,5 heures lorsqu'elles étaient exposées à la lumière et pendant 12,0 heures lorsqu'elles étaient à l'abri de la lumière, avec un niveau de confiance de $95 \%$.

Conclusions : Les solutions extemporanées de lévothyroxine préparées dans du chlorure de sodium à $0,9 \%$ devraient demeurer stables pendant au moins 6,5 heures si elles sont entreposées à la lumière et pendant au moins 12 heures si elles sont entreposées à l'abri de la lumière. La stabilité est liée à la concentration, les solutions plus diluées étant plus stables.

Mots clés : lévothyroxine, administration i.v., stabilité, don d'organe

[Traduction par l'éditeur] 


\section{INTRODUCTION}

$\mathrm{O}$

rgan transplantation is a life-saving treatment for patients with end-stage renal, hepatic, cardiac, lung, or pancreas failure. ${ }^{1,2}$ The majority of transplanted organs come from patients who have died in the intensive care unit (ICU) after declaration of brain death. ${ }^{3}$ During and after brain death, electrocardiographic, hemodynamic, and histopathologic changes occur, with subsequent depletion of circulating hormones and deterioration of organ function, all of which affect the quality of the donor organ and the success of the transplant. Aggressive donor management strategies are required to preserve the function of the donor's organs. ${ }^{3.6}$ One strategy that may improve the viability and function of organs after transplantation is the use in potential donors of combined hormonal therapy consisting of IV administration of levothyroxine, vasopressin, and corticosteroids. ${ }^{3-10}$ The Canadian guidelines on solid organ donor management ${ }^{11}$ endorse the IV administration of levothyroxine.

Pharmacy staff and ICU nurses are reluctant to prepare and administer IV levothyroxine solutions for use in potential solid organ donors because information about their stability is lacking. In a recent study, Stadalman and others ${ }^{12}$ reported that when levothyroxine sodium $40 \mu \mathrm{g} / \mathrm{mL}$ was admixed with $0.9 \%$ sodium chloride to a final concentration of $0.4 \mu \mathrm{g} / \mathrm{mL}$, it was stable for $24 \mathrm{~h}$ at room temperature when protected from light. However, as discussed in more detail later in this article, the authors did not demonstrate that their testing procedure was a stability-indicating method.

The purpose of the study reported here was to examine the physical characteristics and chemical stability (defined as maintenance of more than $90 \%$ of original concentration, as determined by high-performance liquid chromatography [HPLC]) of levothyroxine $0.4 \mu \mathrm{g} / \mathrm{mL}$ and $2.0 \mu \mathrm{g} / \mathrm{mL}$ prepared in $50-\mathrm{mL}$ minibags of $0.9 \% \mathrm{NaCl}$ and stored under both light and dark conditions. These concentrations were chosen because they can be easily prepared and used when following the levothyroxine doses recommended by the Canadian guidelines on solid organ donor management: $20 \mu \mathrm{g}$ IV bolus followed by $10 \mu \mathrm{g} / \mathrm{h}$ IV infusion or $100 \mu \mathrm{g}$ IV bolus followed by $50 \mu \mathrm{g} \mathrm{IV}$ every 12 h. ${ }^{11}$

\section{METHODS}

\section{Preparation of Levothyroxine and Experimental Setup}

Two sets of 6 bags of levothyroxine solution were prepared from commercially available levothyroxine (levothyroxine sodium for injection, $500 \mu \mathrm{g}$ per vial; Pharmaceutical Partners of Canada, Richmond Hill, Ontario; lot 203463, expiry November 2009 [all experiments were completed before the expiry date]). Solutions of levothyroxine $0.4 \mu \mathrm{g} / \mathrm{mL}$ and
$2.0 \mu \mathrm{g} / \mathrm{mL}$ were prepared by diluting the levothyroxine sodium $20 \mu \mathrm{g} / \mathrm{mL}$ and $100 \mu \mathrm{g} / \mathrm{mL}$, respectively, in $0.9 \% \mathrm{NaCl}$ and transferring the solutions to latex-free polyvinylchloride (PVC)-containing 50-mL minibags (Baxter Corporation, Toronto, Ontario; lot JB1301). Three bags of each concentration were exposed to ambient (fluorescent) light, and the remaining bags were stored in the dark (in opaque brown resealable bags). All samples were stored at room temperature $\left(25^{\circ} \mathrm{C}\right.$; range $23.5^{\circ} \mathrm{C}$ to $\left.26.5^{\circ} \mathrm{C}\right)$.

\section{Physical Compatibility}

The physical characteristics of the solutions were evaluated qualitatively at the time of preparation and at $0.5,1.0,1.5,2.0$, 3.0, 4.0, 8.0, 12.0, and $24.0 \mathrm{~h}$. As samples were collected for analysis, each solution was tested by the same individual (D.D.) and was visually examined for changes in colour (against a white background) and for formation of precipitate (against a black background). A 2-mL aliquot was collected from each minibag at each time point for determination of $\mathrm{pH}$. At every time point, the $\mathrm{pH}$ meter (model 8000, VWR International, Mississauga, Ontario) was calibrated with Sigma pH 7.00 and pH 4.00 reference solutions (Sigma-Aldrich, Oakville, Ontario; lots $038 \mathrm{~K} 0073$ and $088 \mathrm{~K} 0735$, respectively).

\section{Chemical Stability Preparation of Stocks and Standards}

Stock solutions of levothyroxine were prepared daily from levothyroxine $1 \mathrm{mg} / \mathrm{mL}$ (Sigma-Aldrich, Oakville, Ontario; lot 097K0753) in $0.9 \% \mathrm{NaCl}$ (Baxter Corporation, Toronto, Ontario; lot WD27MO). The internal standard was propranolol (Sigma Aldrich, Oakville, Ontario; lot 97H0311), diluted to a concentration of $0.5 \mu \mathrm{gg} / \mathrm{mL}$ in HPLC-grade methanol (Fisher Scientific, Richmond, British Columbia; lot 08969535). To prepare stock solutions for constructing the calibration curve, levothyroxine $10 \mu \mathrm{g} / \mathrm{mL}$ was diluted in $0.9 \% \mathrm{NaCl}$ to concentrations of $0.1,0.2,1.0,2.0,4.0$, and $8.0 \mu \mathrm{g} / \mathrm{mL}$. The standards were prepared by combining $0.5 \mathrm{~mL}$ of each stock solution and $0.5 \mathrm{~mL}$ of the internal standard (propranolol $0.5 \mu \mathrm{g} / \mathrm{mL}$ ). The final concentrations of levothyroxine in the standard samples injected onto the chromatograph were $0.05,0.1,0.5,1.0,2.0$, and $4.0 \mu \mathrm{g} / \mathrm{mL}$, and the final concentration of propranolol in each standard was $0.25 \mu \mathrm{g} / \mathrm{mL}$. Before injection onto the chromatograph, all standards were passed through a $0.45-\mu \mathrm{m}$ microfilter to remove impurities.

A 6-point calibration curve was prepared with a blank (water) at the beginning of each run, to ensure that there was no carry-over from one run to the next. The range of this calibration curve $(0.05$ to $4.0 \mu \mathrm{g} / \mathrm{mL})$ encompassed the diluted $(0.2$ and $1.0 \mu \mathrm{g} / \mathrm{mL})$ test concentrations of levothyroxine 0.4 
and $2.0 \mu \mathrm{g} / \mathrm{mL}$. The daily calibration curve was generated by least-squares regression of the peak area ratio of levothyroxine to propranolol (the internal standard) versus the concentration of each levothyroxine standard. The accuracy of the assay was calculated as the mean deviation between nominal and observed concentrations. Precision (reproducibility) of the assay was evaluated by intraday and interday validation methods. The intraday variability was determined by running the standards' lowest limit of quantitation and low, medium, and high concentrations of levothyroxine $(0.1,0.75,1.5$, and $3 \mu \mathrm{g} / \mathrm{mL}$, respectively) in quadruplicate throughout a single day. Interday variability was determined by running samples with the same concentrations (as in the testing for intraday variability) in quadruplicate daily for 4 days. The mean, standard deviation, coefficient of variation, and accuracy were calculated. Acceptable limits for coefficients of variation were defined a priori as less than $10 \%$ and acceptable limits for accuracy were defined a priori as more than $90 \%$.

\section{Preparation of Samples}

Immediately after the physical observations were recorded, 1 -mL samples were transferred to $12 \times 75 \mathrm{~mm}$ glass dilution tubes (VWR International, Edmonton, Alberta) and stored at $-85^{\circ} \mathrm{C}$ until analysis by stability-indicating HPLC with ultraviolet detection.

A $0.5-\mathrm{mL}$ aliquot of each study sample was diluted with $0.5 \mathrm{~mL}$ of propranolol (internal standard) $5 \mu \mathrm{g} / \mathrm{mL}$. The final theoretical levothyroxine concentrations were 0.2 and $1.0 \mu \mathrm{g} / \mathrm{mL}$. Each sample was passed through a $0.45-\mu \mathrm{m}$ microfilter before an $80-\mu \mathrm{L}$ sample was withdrawn and injected onto the column.

\section{HPLC Instrumentation}

The HPLC instrumentation (model 2690, Waters Alliance System, Waters Ltd, Mississauga, Ontario) consisted of a delivery pump, an automatic injector equipped with a $200-\mu \mathrm{L}$ injector, an Atlantis dC18 $4.6 \times 250 \mathrm{~mm}(5-\mu \mathrm{m}$ unbounded silica-based) column (Waters Ltd; lot 013138176136), an Atlantis dC18 $3.9 \times 20 \mathrm{~mm}$ guard column (Waters Ltd; lot 0131383031), and an ultraviolet detector (dual absorbance detector, model 2487; Waters Alliance System) set at $232 \mathrm{~nm}$. The mobile phase consisted of a 28\%-32\%-40\% (v/v/v) mixture of methanol, acetonitrile (VWR International, Edmonton, Alberta; lot 49027), and 0.01 $\mathrm{mol} / \mathrm{L}$ solution of $\mathrm{KH}_{2} \mathrm{PO}_{4}$ (Sigma-Aldrich, Oakville, Ontario; lot 107K0100) at $\mathrm{pH} 3.0$. All solvents were HPLC-grade and were filtered before use. Samples were eluted at room temperature $\left(25^{\circ} \mathrm{C}\right)$, and the flow rate was set at $1.4-1.75 \mathrm{~mL} / \mathrm{min}$ to achieve optimal chromatographic characteristics. Specifically, for each sample, the flow rate at time 0 was $1.4 \mathrm{~mL} / \mathrm{min}$; between 3.5 and $5.0 \mathrm{~min}$, the flow rate was gradually increased from 1.4 to $1.75 \mathrm{~mL} / \mathrm{min}$; and between 5.0 and $8.0 \mathrm{~min}$, the rate was kept constant at $1.75 \mathrm{~mL} / \mathrm{min}$. The assay, developed in the authors' laboratory, was based on previous work of other researchers. ${ }^{13-15}$

\section{Degradation of Levothyroxine}

Levothyroxine $10 \mu \mathrm{g} / \mathrm{mL}$ was prepared from a $1 \mathrm{mg} / \mathrm{mL}$ stock solution. The $\mathrm{pH}$ was first adjusted to 12.4 with sodium hydroxide $1 \mathrm{~N}$ and then returned to 6.0 with sodium hydroxide $1 \mathrm{~N}$. The $\mathrm{pH}$ was then adjusted to 2.1 with hydrochloric acid $1 \mathrm{~N}$ and again returned to 6.0 with sodium hydroxide $1 \mathrm{~N}$. The sample was diluted with water to a final concentration of $4.0 \mu \mathrm{g} / \mathrm{mL}$, combined with an equal volume of the internal standard, filtered, and injected onto the column. A second preparation of levothyroxine $4 \mu \mathrm{g} / \mathrm{mL}$ in $0.9 \% \mathrm{NaCl}$ was exposed to light for a period of $36 \mathrm{~h}$, combined with an equal volume of the internal standard, filtered, and injected onto the column. The chromatograms obtained for these degraded preparations were compared with chromatograms obtained from the standard curve to determine any changes in concentration, retention time, and shape of the peak.

\section{Statistical Analysis}

Mean, standard deviation, coefficient of variation, and accuracy were calculated for samples analyzed in triplicate (experimental samples) and quadruplicate (validation standards). The percentage of initial levothyroxine concentration remaining was calculated for each sample, and stability was defined as maintenance of at least $90 \%$ of the initial levothyroxine concentration. The percentage of levothyroxine remaining at $24 \mathrm{~h}$ was calculated from the concentration at $24 \mathrm{~h}$, as determined by linear regression and concentration at time 0 , according to the following formula: concentration at $24 \mathrm{~h} \div$ concentration at time $0 \times 100 \%$. The $95 \%$ confidence interval (CI) of the amount remaining at $24 \mathrm{~h}$ was calculated from the lower limit of the $95 \%$ CI of the slope of the curve relating concentration to time, determined by linear regression, via computer analysis, according to the following formula: lower limit of the $95 \% \mathrm{CI}$ of the concentration at $24 \mathrm{~h} \div$ concentration at time $0 \times 100 \%$. If the percentage remaining at $24 \mathrm{~h}$ was not at least $90 \%$ of the initial concentration, then the time during which the solution would maintain at least $90 \%$ of its initial concentration was calculated, according to the following formula: $10 \div$ lower limit of the $95 \% \mathrm{CI}$ of the slope of the curve relating concentration to time (determined by linear regression).

\section{RESULTS}

The regression analysis of the peak area ratio of levothyroxine to propranolol (the internal standard) versus the concentration of each levothyroxine standard demonstrated linearity over the range of the concentrations, with coefficient 

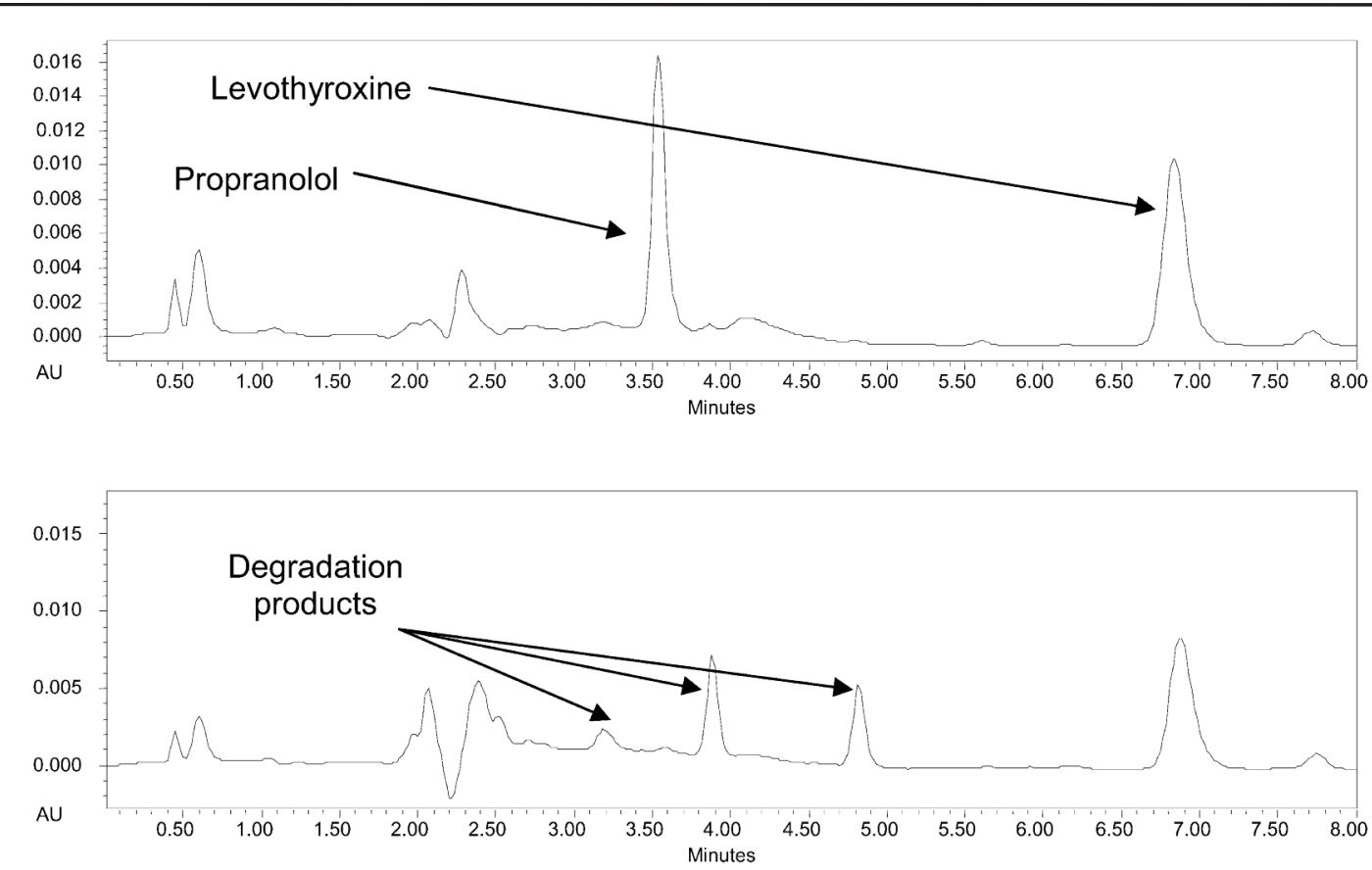

Figure 1. The upper chromatogram shows peaks for the internal standard, propranolol, at 3.5 min and levothyroxine at $6.7 \mathrm{~min}$. The lower chromatogram, representing the degraded preparation, shows 3 non-interfering peaks at 3.2, 3.9, and $4.8 \mathrm{~min}$ and a $32 \%$ reduction in the levothyroxine peak.

\section{Table 1. Percentage of Initial Concentration of Levothyroxine $0.4 \mu \mathrm{g} / \mathrm{mL}^{*}$ Remaining after Storage at $25^{\circ} \mathrm{C}$ in Minibags Exposed to or Protected from Light}

\begin{tabular}{|c|c|c|}
\hline \multirow[b]{2}{*}{ Sampling Time (h) } & \multicolumn{2}{|c|}{$\begin{array}{l}\text { Storage Conditions; \% Remaining } \\
\text { (Mean } \pm \text { SD) }\end{array}$} \\
\hline & Light & Dark \\
\hline Initial concentration $(\mu \mathrm{g} / \mathrm{mL})$ & $0.40 \pm 0.021$ & $0.37 \pm 0.004$ \\
\hline 0.5 & $92.5 \pm 5.5$ & $97.3 \pm 1.3$ \\
\hline 1.0 & $97.5 \pm 2.8$ & $94.6 \pm 4.5$ \\
\hline 1.5 & $95.0 \pm 1.5$ & $94.6 \pm 6.5$ \\
\hline 2.0 & $90.0 \pm 2.3$ & $91.9 \pm 2.3$ \\
\hline 3.0 & $92.5 \pm 7.0$ & $97.3 \pm 1.5$ \\
\hline 4.0 & $95.0 \pm 3.5$ & $100.0 \pm 5.0$ \\
\hline 8.0 & $90.0 \pm 3.3$ & $91.9 \pm 6.8$ \\
\hline 12.0 & $90.0 \pm 2.8$ & $91.9 \pm 0.8$ \\
\hline 24.0 & $90.0 \pm 1.3$ & $91.9 \pm 2.0$ \\
\hline $\begin{array}{l}\text { \% remaining at } 24 \mathrm{~h} \text { by linear } \\
\text { regressiont }\end{array}$ & 93.4 & 94.1 \\
\hline $\begin{array}{l}\text { Lower limit of } 95 \% \mathrm{Cl} \text { for } \\
\% \text { remaining } \neq\end{array}$ & 85.8 & 86.9 \\
\hline $\begin{array}{l}\text { Time predicted to maintain at least } \\
90 \% \text { of initial concentration§ }\end{array}$ & $16.9 \mathrm{~h}$ & $18.3 \mathrm{~h}$ \\
\hline \multicolumn{3}{|c|}{$\begin{array}{l}\mathrm{Cl}=\text { confidence interval, SD = standard deviation. } \\
* \text { Nominal concentration. } \\
\text { +Calculated from concentration at } 24 \mathrm{~h} \text { as determined by linear regression and } \\
\text { concentration at time zero, according to the following formula: concentration at } 24 \mathrm{~h} \div \\
\text { concentration at time zero } \times 100 \text {. } \\
\neq \text { Calculated from lower limit of } 95 \% \mathrm{Cl} \text { of the slope of the curve relating concentration } \\
\text { to time, determined by linear regression, according to the following formula: lower limit } \\
\text { of } 95 \% \text { confidence interval of concentration at } 24 \mathrm{~h} \div \text { concentration at time zero } \times 100 \\
\S C \text { alculated according to the following formula: } 10 \div \text { lower limit of the } 95 \% \mathrm{Cl} \text { of the } \\
\text { slope of the curve relating concentration to time (determined by linear regression). }\end{array}$} \\
\hline
\end{tabular}


Table 2. Percentage of Initial Concentration of Levothyroxine $2.0 \mu \mathrm{g} / \mathrm{mL}^{*}$ Remaining after Storage at $25^{\circ} \mathrm{C}$ in Minibags Exposed to or Protected from Light

\begin{tabular}{|c|c|c|}
\hline \multirow[b]{2}{*}{ Sampling Time (h) } & \multicolumn{2}{|c|}{$\begin{array}{c}\text { Storage Conditions; \% Remaining } \\
\text { (Mean } \pm \text { SD) }\end{array}$} \\
\hline & Light & Dark \\
\hline Initial concentration $(\mu \mathrm{g} / \mathrm{mL})$ & $1.91 \pm 0.013$ & $1.94 \pm 0.038$ \\
\hline 0.5 & $103.1 \pm 1.0$ & $99.0 \pm 6.4$ \\
\hline 1.0 & $103.1 \pm 7.7$ & $99.0 \pm 9.1$ \\
\hline 1.5 & $100.0 \pm 15.6$ & $104.1 \pm 0.3$ \\
\hline 2.0 & $103.1 \pm 3.0$ & $102.6 \pm 0.9$ \\
\hline 3.0 & $100.5 \pm 2.1$ & $96.4 \pm 0.8$ \\
\hline 4.0 & $102.6 \pm 5.6$ & $105.7 \pm 4.9$ \\
\hline 8.0 & $104.7 \pm 4.1$ & $97.4 \pm 1.4$ \\
\hline 12.0 & $96.9 \pm 3.3$ & $104.6 \pm 4.2$ \\
\hline 24.0 & $73.8 \pm 4.1$ & $89.2 \pm 12.3$ \\
\hline $\begin{array}{l}\text { \% remaining at } 24 \mathrm{~h} \text { by linear } \\
\text { regressiont }\end{array}$ & 74.3 & 90.9 \\
\hline $\begin{array}{l}\text { Lower limit of } 95 \% \mathrm{Cl} \text { for } \\
\% \text { remaining }\end{array}$ & 63.1 & 80.4 \\
\hline $\begin{array}{l}\text { Time predicted to maintain at least } \\
90 \% \text { of initial concentration§ }\end{array}$ & $6.5 \mathrm{~h}$ & $12.3 \mathrm{~h}$ \\
\hline \multicolumn{3}{|c|}{$\begin{array}{l}\mathrm{Cl}=\text { confidence interval, SD = standard deviation. } \\
* \text { Nominal concentration. } \\
\text { +Calculated from concentration at } 24 \mathrm{~h} \text { as determined by linear regression and } \\
\text { concentration at time zero, according to the following formula: concentration at } 24 \mathrm{~h} \div \\
\text { concentration at time zero } \times 100 \text {. } \\
\text { ₹Calculated from lower limit of } 95 \% \mathrm{Cl} \text { of the slope of the curve relating concentration } \\
\text { to time, determined by linear regression, according to the following formula: lower limit } \\
\text { of } 95 \% \text { confidence interval of concentration at } 24 \mathrm{~h} \div \text { concentration at time zero } \times 100 \\
\S \text { Calculated according to the following formula: } 10 \div \text { lower limit of the } 95 \% \mathrm{Cl} \text { of the } \\
\text { slope of the curve relating concentration to time (determined by linear regression). }\end{array}$} \\
\hline
\end{tabular}

of determination $\left(r^{2}\right)$ greater than $0.999(n=4)$. The intraday and interday coefficients of variation were within acceptable limits (<10\%): $5.30 \%$ and $2.39 \%$ at $0.1 \mu \mathrm{g} / \mathrm{mL}, 5.55 \%$ and $6.15 \%$ at $0.75 \mu \mathrm{g} / \mathrm{mL}, 3.55 \%$ and $8.50 \%$ at $1.5 \mu \mathrm{g} / \mathrm{mL}$, and $3.68 \%$ and $3.94 \%$ at $3 \mu \mathrm{g} / \mathrm{mL}$, respectively. Intraday and interday accuracy was also within acceptable limits (>90\%): $95.7 \% \pm 2.7 \%$ and $95.5 \% \pm 6.4 \%$ at $0.1 \mu \mathrm{g} / \mathrm{mL}, 91.5 \% \pm$ $6.1 \%$ and $91.5 \% \pm 7.8 \%$ at $0.75 \mu \mathrm{g} / \mathrm{mL}, 93.5 \% \pm 3.7 \%$ and $98.1 \% \pm 8.5 \%$ at $1.5 \mu \mathrm{g} / \mathrm{mL}$, and $97.0 \% \pm 2.6 \%$ and $99.0 \% \pm$ $5.7 \%$ at $3.0 \mu \mathrm{g} / \mathrm{mL}$, respectively. The lower limit of detection was $0.025 \mu \mathrm{g} / \mathrm{mL}$. The retention times were $6.7 \mathrm{~min}$ for levothyroxine and $3.5 \mathrm{~min}$ for propranolol (Figure 1).

In the degradation studies (at room temperature), small non-interfering peaks formed and the area of the peak was reduced when the $\mathrm{pH}$ was adjusted to 12.4 , and further degradation occurred when the $\mathrm{pH}$ was adjusted to 2.1: the levothyroxine peak was reduced by $32 \%$ and 3 degradation peaks were detected at 3.2, 3.9, and $4.8 \mathrm{~min}$. No interfering peaks were detected (Figure 1). When exposed to light for a period of $36 \mathrm{~h}$, the concentration of levothyroxine decreased by $67.5 \%$, but no degradation peaks were observed on the chromatogram. Thus, the HPLC method was deemed capable of indicating stability.
No notable changes in $\mathrm{pH}$ or colour were observed, and no precipitation occurred in any of the solutions. The mean $\mathrm{pH}$ values ( \pm standard deviation) were $6.10 \pm 0.38$ and $6.12 \pm 0.41$, for levothyroxine $0.4 \mu \mathrm{g} / \mathrm{mL}$ exposed to ambient light and stored in the dark, respectively, and $6.96 \pm 0.10$ and $6.98 \pm$ 0.11 for levothyroxine $2.0 \mu \mathrm{g} / \mathrm{mL}$ exposed to ambient light and stored in the dark, respectively.

The HPLC analysis showed that none of the levothyroxine solutions exposed to light or kept in the dark was stable for $24 \mathrm{~h}$ (Tables 1 and 2). However, based on the 95\% confidence interval of the slope determined by linear regression, levothyroxine $0.4 \mu \mathrm{g} / \mathrm{mL}$ can be expected to maintain at least $90 \%$ of the initial concentration for $16.9 \mathrm{~h}$ (storage in the light) or $18.3 \mathrm{~h}$ (storage in the dark), with $95 \%$ confidence (Table 1). Levothyroxine $2.0 \mu \mathrm{g} / \mathrm{mL}$ can be expected to maintain at least $90 \%$ of the initial concentration for $6.5 \mathrm{~h}$ (storage in the light) and $12.3 \mathrm{~h}$ (storage in the dark), with $95 \%$ confidence (Table 2 ).

\section{DISCUSSION}

Data on the stability of levothyroxine for IV use are very limited. The product monograph for levothyroxine sodium for injection (Pharmaceutical Partners of Canada Inc) recommends that $5 \mathrm{~mL}$ of $0.9 \% \mathrm{NaCl}$ for injection, USP, be added 
to the lyophilized drug for reconstitution, that the product be used immediately after reconstitution, that the solution be protected from light, and that the solution not be combined with other IV fluids. ${ }^{16}$ The Micromedex database states that levothyroxine for IV use should be reconstituted with normal saline, shaken, used immediately, and not added to other IV fluids. ${ }^{17}$ However, a study examining the stability of levothyroxine $100 \mu \mathrm{g} / \mathrm{mL}$ in $0.9 \% \mathrm{NaCl}$ in polypropylene syringes found no change in clarity, $\mathrm{pH}$, or potency after 7 days of storage at $5^{\circ} \mathrm{C}^{18}$ Stadalman and others ${ }^{12}$ recently reported that levothyroxine sodium (Bedford Laboratories, Bedford, Ohio) $40 \mu \mathrm{g} / \mathrm{mL}$ admixed with $500 \mathrm{~mL} 0.9 \% \mathrm{NaCl}$ to a final concentration of $0.4 \mu \mathrm{g} / \mathrm{mL}$ was stable for $24 \mathrm{~h}$ at room temperature when protected from light. However, the assay was not deemed to be stability-indicating. ${ }^{19}$ In addition, the investigators used the ADVIA Centaur T4 assay (Siemens Healthcare Diagnostics Inc, Deerfield, Illinois), a competitive immunoassay that uses direct chemiluminescent technology and quantifies the amount of thyroxine in serum. It is possible that the assay did not distinguish between levothyroxine and its degradation products, which would explain the significant increase in measured levothyroxine concentrations over time. ${ }^{12}$

In the current study, we used a stability-indicating HPLC method to assay levothyroxine, testing 2 concentrations of the drug that are recommended by the Canadian guidelines on solid organ donor management (i.e., $0.4 \mu \mathrm{g} / \mathrm{mL}$ for infusion and $2 \mu \mathrm{g} / \mathrm{mL}$ for bolus infusion) under both light and dark conditions.

We noted an interesting finding during the assay validation of the study. When levothyroxine samples were stored at $-85^{\circ} \mathrm{C}$ following preparation and then thawed for analysis, the levothyroxine peak was reduced by up to $60 \%$ after 2 freeze-thaw cycles. For levothyroxine $2 \mu \mathrm{g} / \mathrm{mL}$, the percentage of the initial concentration decreased steadily, by $26.0 \%$ at $24 \mathrm{~h}$ and by $44.1 \%$ at $48 \mathrm{~h}$ for the solutions exposed to light and by $11.4 \%$ at $24 \mathrm{~h}$ and by $21.9 \%$ at $48 \mathrm{~h}$ for the solutions kept in the dark. The impact of freezing the samples before analysis may be what has contributed to the controversy about levothyroxine stability in IV fluids in previous studies.

\section{CONCLUSIONS}

Levothyroxine solutions $(0.4 \mu \mathrm{g} / \mathrm{mL}$ and $2.0 \mu \mathrm{g} / \mathrm{mL})$, prepared extemporaneously in $0.9 \% \mathrm{NaCl} 50-\mathrm{mL}$ minibags and stored at room temperature, can be expected to be stable (defined as maintenance of more than $90 \%$ of original concentration) for $16.9 \mathrm{~h}$ and $6.5 \mathrm{~h}$, respectively, when stored in the light and for $18.3 \mathrm{~h}$ and $12.3 \mathrm{~h}$ when stored in the dark. Pharmacists can be confident that preparations of levothyroxine in $0.9 \% \mathrm{NaCl}$ at these 2 concentrations prepared for IV administration to potential organ donors will be stable for up to $12 \mathrm{~h}$ if stored under dark conditions.

\section{References}

1. Canadian Institute for Health Information, Canadian Organ Replacement Register. Treatment of end-stage organ failure in Canada 1998 to 2007. 2009 annual report. Ottawa (ON): The Institute; 2010 [cited 2010 Nov 7]. Available from: http://secure.cihi.ca/cihiweb/products/corr_annual_report_ 2009_en.pdf

2. Policy management: policies. US Department of Health and Human Services, Organ Procurement and Transplantation Network; [cited 2010 Apr 26]. Available from: http://optn.transplant.hrsa.gov/ policiesAndBylaws/policies.asp

3. Mascia L, Mastromauro I, Viberti S, Vincenzi M, Zanello M. Management to optimize organ procurement in brain dead donors. Minerva Anestesiol 2009;75(3):125-133.

4. Rosendale JD, Kauffman HM, McBride MA, Chabalewski FL, Zaroff JG, Garrity ER, et al. Aggressive pharmacological donor management results in more transplanted organs. Transplantation 2003;75(4):482-487.

5. Kutsogiannis DJ, Pagliarello G, Doig C, Ross H, Shemie S. Medical management to optimize donor organ potential: review of the literature. Can J Anaesth 2006;53(8):820-830.

6. Wood KE, Becker BN, McCartney JG, D'Alessandro AM, Coursin DB. Care of the potential organ donor. NEngl J Med 2004;351(26):2730-2739.

7. Salim A, Vassiliu P, Velmahos GC, Sava J, Murray JA, Belzberg H, et al. The role of thyroid hormone administration in potential organ donors. Arch Surg 2001;136(12):1377-1380.

8. Novitzky D, Cooper DKC, Rosendale JD, Kauffman HM. Hormonal therapy of the brain-dead organ donor: experimental and clinical studies. Transplantation 2006;82(11):1396-1401.

9. Rosendale JD, Kauffman HM, McBride MA, Chabalewski FL, Zaroff JG, Garrity ER, et al. Hormonal resuscitation yields more transplanted hearts, with improved early function. Transplantation 2003;27(8):1336-1341.

10. Salim A, Martin M, Brown C, Inaba K, Roth B, Hadjizacharia P, et al. Using thyroid hormone in brain dead donors to maximize the number of organs available for transplantation. Clin Transplant 2007;21(3):405-409.

11. Shemie SD, Ross H, Pagliarello J, Baker AJ, Greig PD, Brand T, et al. Organ donor management in Canada: recommendations of the forum on Medical Management to Optimize Donor Organ Potential. CMAJ 2006; 174(6):S13-S30.

12. Stadalman KA, Kelner MJ, Box K, Dominguez A, Rigby JF. Stability of levothyroxine sodium $0.4 \mu \mathrm{g} / \mathrm{mL}$ in $0.9 \%$ sodium chloride injection. Progr Transplant 2009;19(4):354-356.

13. Shah RB, Bryant A, Collier J, Habib MJ, Khan MA. Stability indicating validated HPLC method for quantification of levothyroxine with eight degradation peaks in the presence of excipients. Int J Pharm 2008;360 (1-2):77-82.

14. Richheimer SL, Amer TM. Stability-indicating assay, dissolution, and content uniformity of sodium levothyroxine in tablets. J Pharm Sci 1983;72(11):1349-1351.

15. Garnick RL, Burt GF, Long DA, Bastian JW, Aldred JP. High-performance liquid chromatographic assay for sodium levothyroxine in tablet formulations: content uniformity applications. J Pharm Sci 1984;73(1):75-77.

16. Levothyroxine sodium for injection [product monograph]. Richmond Hill (ON): Pharmaceutical Partners of Canada Inc; 2008 Jan 14.

17. Levothyroxine (DrugDex evaluations). In: DrugDex System, Micromedex 1.0 Healthcare Series. Greenwood Village (CO): Thomson Reuters Healthcare; [cited 2010 Nov 9]. Available from www.thomsonhc.com/ hcs/librarian/ ND_T/HCS/ND_PR/Main/CS/D2730A/DUPLICATIONSHIELDSYNC/ FD3BE6/ND_PG/PRIH/ND_B/HCS/SBK/2/ND_P/Main/ PFActionId/hcs.common. RetrieveDocumentCommon/DocId/2542/ ContentSetId/31\#storageAndStabilitySection. Subscription required to access content.

18. Das Gupta V. Stability of levothyroxine in polypropylene syringes. Int J Pharm Comp 2000;4(6):482-483.

19. Trissel LA. Avoiding common flaws in stability and compatibility studies of injectable drugs. Am J Hosp Pharm 1983;40(7):1159-1160. 
Dawn K Strong, BSCPhm, PharmD is Pharmacy Coordinator, British Columbia Transplant, an agency of the Provincial Health Services Authority, Vancouver, British Columbia.

Diane Decarie, BSc, is Research Consultant, Department of Pharmacy, Children's and Women's Health Centre of British Columbia, Vancouver, British Columbia.

Mary H H Ensom, PharmD, FASHP, FCCP, FCSHP, FCAHS, is Professor and Director, Doctor of Pharmacy Program, Faculty of Pharmaceutical Sciences, and Distinguished University Scholar, University of British Columbia, and Clinical Pharmacy Specialist, Children's and Women's Health Centre of British Columbia, Vancouver, British Columbia. She is also the Editor of the CJHP.

\section{Address correspondence to:}

Dr Mary H H Ensom

Department of Pharmacy (OB7)

Children's and Women's Health Centre of British Columbia

4500 Oak Street

Vancouver BC V6B 6E4

e-mail: ensom@interchange.ubc.ca

\section{Acknowledgements}

We thank Mariette Carter, Penny Clarke-Richardson, Ed Ferre, and Laslo Kalmar of the Organ Donation and Hospital Development Team, British Columbia Transplant, for their clinical insights and suggestions. The study was supported by British Columbia Transplant.

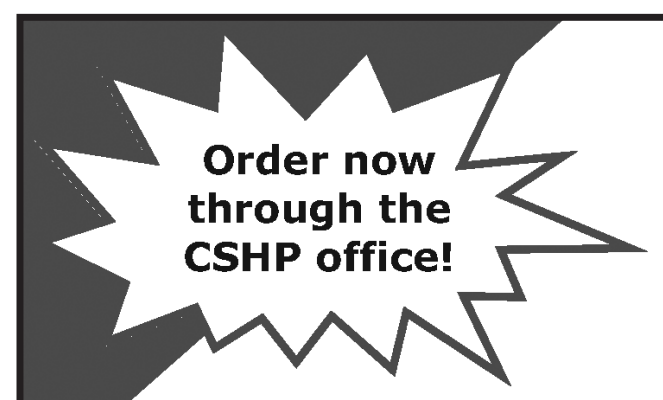

\section{Safe and Effective}

The Eight Essential Elements of an Optimal Medication-Use System

Editor: Neil J. MacKinnon, PhD, FCSHP

Medication is the most relied-upon treatment in health care today. Despite its importance, the current medication-use system suffers from problems related to lack of safety and quality. Safe and Effective explores the medication-use system and, more importantly, provides concrete and straightforward strategies for improving it.

"The patient safety movement is profoundly changing the face of modern health care. This effort by Neil Mackinnon and his capable and progressive group of colleagues is a "must read" for clinicians, practitioners, academics and students who are part of this important journey. This addition to the literature will assist in advancing patient safety practices for Canadian caregivers and will most certainly benefit those we all serve."

$$
\text { - Phil Hassen, CEO, Canadian Patient Safety Institute }
$$

Now available to order through the CSHP office - $\$ 81$ for CSHP members and $\$ 90$ for nonmembers (plus applicable taxes and shipping). Please find our order form online at www.cshp.ca under the "Products and Publications" drop-down menu. 